\title{
Relationship between Leverage and Firm Size Toward to Real Earning Management (Unit Analysis of Mining Company Indonesia Exchange Stock Period 2012 Until 2015)
}

\author{
Irene Sukma Lestari Barus ${ }^{1,{ }^{*}}$, Tetty Lasniroha Sarumpaet ${ }^{1}$, Acep Edison ${ }^{1}$, \\ Renny Maisyarah², Edrida Pulungan ${ }^{3}$ \\ ${ }^{1}$ Universitas Widyatama, Jl. Cikutra No.204 A Bandung, Indonesia \\ ${ }^{2}$ Universitas Pembangunan Pancabudi, Jl. Gatot Subroto Km 4 Medan, Indonesia \\ ${ }^{3}$ The Representative Office Council of the Republic of Indonesia and Universitas Satyagama, Jl. Jenderal \\ Gatot Subroto Senayan Kebayoran Baru, Jakarta, Indonesia and Jl. Kamal Raya No.2a, RT.11/RW.8, Kamal, \\ Kecamatan Cengkareng, Kota Jakarta Barat, Daerah Khusus Ibukota Jakarta 11730, Indonesia
}

\begin{abstract}
This study found new results from the development of previous research. Previous research, earnings management is measured through discreationary accruals by disbursing total accruals with non-discreationary accruals using the Jones Modified model (Dechow et al., 1995) with the formula TA = Nit - CFOit. Previous research and this study were conducted on mining companies listed on the Indonesian stock exchange in the period 2012 to 2015 . The results of previous studies that leverage had no effect on earnings management and earnings management is an intervening variable that has a significant influence on earnings quality. (Irene Barus et al., 2018). This study aims to analyze the relationship between leverage ratio and firm size to real earnings management using discretionary accruals through real daily earnings management activities. Managers tend to choose earnings management through real activity manipulation rather than earnings management through accruals (Graham et al. 2005; Roychowdhury (2006: 338). The results of this study indicate leverage variables have a positive and significant effect on real earnings management activities.
\end{abstract}

Keywords: Leverage, Firm Size, Real Earning Management.

\section{INTRODUCTION}

Some stocks of public company are owned by the society through stock exchange. The company has an obligation to present their financial statement based on the requirements established by an authorized institution in Indonesia i.e., Financial Services Authority (OJK). In general, all sections in the financial statement are very important for making decision. However, most of the users of financial statement more focus on the information on profit that is available in the financial statement without paying attention on the relevancy to principle of accounting standard that is existed. Generally, the users only focus on the procedures that are used for generating profit and loss. The profit and loss statement becomes a product of information issued by the company's management. It becomes one of the company's performance indicators that cannot be separated from the composing process. The inclination to focus on the company's profit becomes the basis of the manager's behavior that tends to perform earnings management practices. Up until now, the financial statement has become a central issue and

*Address correspondence to this author at the Universitas Widyatama, Jl. Cikutra No.204 A, Kota Bandung, Indonesia; Tel: +62227275855;

Fax: +62227202997; E-mail: irene.sukma@widyatama.ac.id it is considered as the source of manipulation from the information that can damage the relevant parties in the company. This study is a new discovery from the development of our previous research. Previous research was also carried out on mining companies listed on the Indonesian stock exchange in the period 2012 to 2015. Our previous results showed that leverage did not affect earnings management through discretionary accruals that were calculated by deducting non-discretionary accruals from the total accruals, but earnings management through discretionary accruals, it affects the quality of earnings generated. Where in previous research Earnings management in this study is measured through discreationary accruals which are calculated by disbursing total accruals with non-discreationary accruals by using Total Accrual (TA) classified into Discreationary Accrual (DA) and Non Discreationary Accrual (NDA). In calculating the discreationary accrual, the Modified Jones model is used (Dechow et al., 1995). Previous research can be concluded that the mining company does not take earnings management actions on accrual principles so that it is believed that mining companies apply the principles of accrual method as stipulated in the principles of financial accounting standards in Indonesia (Irene Barus et.al, 2018).

(c) 2019 Lifescience Global 
The manager prefers the earnings management through real activity manipulation to earnings management through accrual (Graham et al. 2005). There are two reasons for the shifting phenomenon from earnings management through accrual to earnings management through real activity manipulation according to Roychowdhury (2006: 338). First, earnings management through accrual manipulation has a higher possibility in attracting the auditor's and the regulator's attentions or the stakeholder's attention than the real decisions such as, pricing and production. Second, the manager who only relies on the accrual manipulation will be at risk if the realization of deficit year-end between non-manipulated profit and the expected profit is more than the possible amount to perform accrual manipulation after the end of period. Earnings management through real activity manipulation can be performed through cash flow from operation, overproduction cost, and discretionary expenditures (Detchow, et al. 1998; Roychowdhury, 2006:337). This research study has the objectives to examine the practice of profit management with these three activities because generally mining companies registered in Indonesia manipulating their sales by reducing discretionary costs but reporting overproduction or increasing production and reports of a low cost of goods. This research study only examines the managers who move from manipulation through accruals to the real activity of manipulation. It can be proven by some researches about the indication of earnings management through real activities as a research done Graham, et al. (2005). In his research, it is found that the managers prefer earnings management through real activities manipulation to accrual based earnings management as well as the researches done by Detchow, et al. (1998) and Roychowdhury (2006: 337). The motivation of this research was carried out again because of the phenomenon of the incident fraud case in reporting the financial condition had ever happened in large-sized companies such as Xerox, Eron, Worldcom, Adelphia, Microstrategy, and etc. (Stice et al. 2007). In 2001, some mining companies in Indonesia experienced company's financial scandal involving the problem of financial statement that was issued like what had happened in PT Lippo Tbk and PT Kimia Farma. Besides, within 2003 - 2008, Indonesia Coruption Watch (ICW) had been reporting the sales of three mining companies owned by Bakrie Group to Director General of Taxation. ICW speculated that the report manipulation had been done at PT Bumi Resources Tbk and the subsidiary company since 2003 until 2008 and it caused financial state losses of US\$ 620.49 million. The coordinator of Monitoring and Budget Analysis Division of ICW, Firdaus llyas, stated that PT Kaltim Prima Coal (KPC), PT Arutmin Indonesia (Arutmin), and the parent company of those two companies i.e., PT Bumi Resources Tbk (Bumi) had also manipulated their the sales report. The calculation result done by ICW using any primary data including audited financial statement shows the sales report of Bumi within 2003 - 2008 that is less than US\$ 1.06 billion from as it should be.

According to Scott (2003), the motivation of earnings management includes bonus plan, debt covenant, and political cost. In general, earnings management can be done by two ways i.e., accrual manipulation and real activity manipulation. Most of people state that the companies increase earnings management (AM or RM) to decrease the possibility of doing contract violation (for example, DeFond and Jiambalvo: 1994, Sweeney: 1994, Jaggi and Lee: 2002, for RM). In this paper, the writers suggest that the managers tend to use their reporting policy to give an impact to financial leverage in the centre of turbulence and the company level plays an important role toward profit manipulation through the management's real activities. The managers have a freedom for financial reporting due to the flexibility that is offered in the accounting standards at this moment. On the other side, high liquidity allows the manager in an absence of the correct company's management structure in manipulating the profits (earnings) (Gombolaa, et al. 2016). Watts and Zimmerman (1986) state that the higher debt/equity of the company is, the closer (the stricter) the company to the limits existed in debt agreement is. The greater opportunity for violation of agreement and the technical failure cost is, the bigger possibility for the managers is in using accounting methods for increasing the profits. Leverage affects the level of after tax revenue and the variability. Consequently, it affects the risk level and company's return in a whole. The higher leverage level has a meaning that the uncertainty level of return is high, however, the amount of return that will be given is also high (Van Horne et al. 2008). Leverage is a tool to measure the size of the company by regarding the creditor in financing the company's assets. The level of leverage of each company will be various. The level of leverage in a certain company can also be various from one period to another period. Therefore, in this research, leverage is measured by using debt ratio since the debt ratio is the company's ability to fulfill their long-term obligation. Besides, the profit target that has been reached shows the company's good 
performance, even though it comes from manipulation and it does not illustrate the real condition of the company. This situation can decrease the firm's value or the firm size in the future. The firm size was a independent variable in this research. In this research, proxy used for measuring the firm size was the total assets. The unit for analysis in this research was mining companies which were listed on Indonesia's Stock Exchange.

The companies were categorized as large-sized companies according to Law 20 Year 2008 Article 6 and the stipulation by Securities and Exchange Commission 11 / PM / 1997 as the amendment of Kep55 / PM / 1996. Regarding the Law and stipulation, the firm size is measured by the total assets (excluding land and building) and the revenue and it consists of three categories i.e., small, medium, and large. The mining companies in Indonesia are included as largesized companies as they use more financial capital. It shows that the net worth (total assets) is greater than a hundred billion dollars. Based on the stipulation of Securities and Exchange Commission 11 / PM / 1997 as the amendment of Kep-55 / PM / 1996, the firm size used in this research was observed from the networth of the total assets owned by the company. Beside the total assets that becoming the measurement in categorizing the company to be a small, medium, or a large company, there is another way to determine the firm size. Brigham and Louis (2007: 119) defined that the size or firm size was considered as the total of average net sales in a certain year during some years. The firm size is the company's characteristic related to the company's structure. In Brazil's capital market, as happened in US, the analysts frequently use leverage ratio as a determinant in evaluating the company's risk like what happens in Indonesia. The background of the literature reveals that the company tends to avoid the damage of doing reporting. Burgstahler and Dichev: 1997, and DeGeorge, Patel, and Zechhauser: 1999) showed that the investor wanted to observe the positive result. Therefore, the writers expected that the company with higher leverage ratio would have higher incentive to manage their revenue since they should give a good result to the lender so that they could pay the company's debts. In this case, it can be concluded that if a company is able to pay its debt, it means the company can achieve its profit target. McConnell e Servaes (1995) and Lang et al. (1996) showed that financial leverage had a negative impact toward the company's investment. It has a meaning that people with high leverage often have lower investment. It is of course become a criterion for the company.
A research done by Zang (2012) found that the manager preferred real activity manipulation to accrual, yet the manager was still preserving the two techniques to reach the expected profit target. It is in line with a research done by Cohen and Zarowin (2010). Earnings management through real activities can be defined as the management's actions that are different from a normal business practice done by the company to achieve the expected profit target (Roychowdhury, 2006). (Roychowdhury, 2006), in his research, found that the managers performed earnings management through real activities manipulation, cash flow from operation, production costs, and discretionary expenditures. Earnings management is one of the important aspects for the financial reporting quality and it is the main problem among the company's stakeholders. Based on the conditions that occur in mining companies in Indonesia, the company's leverage and size are of particular concern to determine the profit generated. It is supported by some theories and previous studies. In this research, earnings management is performed through real activities since the real activities done by the company will affect the continuity of the company in the future when leverage and firm size is the independent and real earnings management activities are the dependent variables in this company. The variables used in this research can be used by the company to generate some profits. If leverage is used correctly, more revenue can be obtained from the fixed cost that has been spent. Leverage can also be used to increase the firm's value.

This paper contributes to the literature that examines the relationship between leverage and company size to profit management. In addition, the results showed the beneficial consequences of debt because the increase in debt will reduce the manager's discretionary expenses and reduce the accrual of profit management. In this study assessing the amount of debt owned shows the ability of the company to pay its debts by using assets owned as company size.The greater of asset value reflects the more profit they can achieve from the sales. Thus, it can guarantee that the company is able to pay their debts back. It can also motivate the manager to perform earnings management in enlarging the firm size in order to avoid the debt covenant violation. The debt covenant violation gives a significant impact towards the firm size. In this case, the profit will usually be reported higher. It is done for keeping the reputation of the company from the external parties' perspectives since the companies that have high portion of debt will 
experience difficulties for getting additional funds from the creditor. In fact, the companies are endangered to violate the debt covenant as stated in debt covenant hypothesis (Watts and Zimmerman, 1986). From the research background explained above, it can be found that the aims of this paper are to check the accuracy of 3 (three) hypotheses about the relationship in this research, such as:

$\mathrm{H} 1$ : Leverage has an relationship towards real earnings management activities in mining companies listed on Indonesia's Stock Exchange (BEI) within the period of 2012 - 2015.

H2: Firm size has an relationship towards real earnings management activities in mining companies listed on Indonesia's Stock Exchange (BEI) within the period of $2012-2015$.

H3: Leverage and firm size have an relationship towards real earnings management activities in mining companies listed on Indonesia's Stock Exchange (BEI) within the period of 2012 - 2015.

\section{LITERATURE REVIEW}

\subsection{Theoretical Framework}

There are some theoretical perspectives about public company for the scholars in exploring the issues of earnings management. These theories are agency theory, disfunctional behaviour theory, capital structure theory, theory of earnings management.

\subsection{Agency Theory}

Agency theory is based on the economic theory exposed by Alchian and Demsetz (1972) and developed deeper by Jensen and Meckling (1976). The agency theory assumes that all individuals take an action for their own interest. The agency theory is introduced by Jensen and Meckling (1976) at the first time. Agency relationship occurs as the contractual agreemeent between the shareholder (the principal) and the company's management (the agent) that is the manager of the company. In the contract, the owner gives an authority to the management in conducting the company's operation including in decision-making. This theory recommends that the shareholder (as the owner or the company's chief operation officer) uses the agent's service to perform the work, yet the company's owner delegates the business operations to the directors or the managers (the agent of shareholder) (Clarke, 2004). Thus, the problem of agency can occur when a part of them (the principal) has a contract with other part (the agent) to make a decision for the doer. The problem of agency will occur as the agent can hide the information and manages the company for their own interest, such as some cases happened in Adelphia, Enron, WorldCom, and Parmalat. According to Anthony and Govindarajan (2003), "one of the key elements from the agency theory is that the principal and the agent have different preference or different goal".

\subsection{Dysfunctional Behavior Theory}

Dysfunctional Behavior Theory: Hansen and Mowen (2005: 299) define dysfunctional behavior as: "Dysfunctional behavior is individual behavior that is basic in conflict with the goals of the organization". Research study related to the acceptance of dysfunctional behavior has shown a strong correlation between locus of control and the individual's willingness to manipulate and cheat (Gable and Dangello 1994; Comer 1985; Solar and Bruehl 1971). Jaworski and Young (1992) defines dysfunctional behavior as the behavior of a subordinate who tries to manipulate the control system et for his/her personal goals by intentionally interfering or violate the rules and procedures. In connection with this case, there are 2 (two) related issues, namely: 1) Gaming Performance Indicator. (Ridgway1956; Birnberg et.al 1983; Kerr 1975; Porter et al. 1975); 2) Strategic Information Manipulation (Binberg et al. 1983).

\subsection{Capital Structure Theory}

One of the significant issues in financial management is the capital structure because it determines the success of management in creating other financial decisions. The capital structure is described as follows: "Capital structure is permanent expenditure which reflects the balance between longterm debt and own capital". In line with this statement, Peterson and Fabozzi (2003) provides the following definition: "Capital structure is the combination of debt and equity used to finance a company's project. The capital structure of a company is some mix of debt, internally generated equity, and new equity". A mix of debt and equity to finance the company is the main topic of capital structure decision. An efficient capital mix can reduce the cost of capital, which can increase net economic returns and increase the value of the company. Currently, there is no appropriate mathematical formula to determine the optimal amount of debt and equity in the capital structure (Seitz, 1984: 
301). The capital structure theory used in this research study is a theory based on management behavior. This theory states in parties related to the company do not have the same information about the prospects and risks of the company. Certain parties have more information than others. This theory consists of:

a. Myers and Majluf Theory: According to this theory, there is an information asymmetry between the managers and the outsiders. The manager has complete information about the condition of the company compared to the outsiders.

b. Signaling: Developing a model in which capital structure (debt use) is a signal delivered by managers to the market. If a manager has confidence that the company has a good prospect and the manager wants the shares to increase, therefore, he/she needs to communicate it to the investors. Managers can use more debt as a more credible signal. The increasing debt of a company can be an indicator that the company is confident with its prospects in the future. Investors are expected to catch the signal; a signal that the company has high-grade prospects. Factors affecting capital structure include: Assets Structure (Brigham and Houston; 2006); and Company Size (Brigham and Houston, 2006).

\subsection{Theory of Earnings Management}

The shifting phenomenon from earnings management through accrual manipulation to earnings management through real activities according to Roychowdhury (2006: 338) can be happened because of two reasons. First, earnings management through accrual manipulation has a great possibility to attract the auditor's attention and the regulator's or the stakeholder's attention more than the real decisions such as pricing and production. Second, the manager who only relies on the accrual manipulation will be at risk if the realization of year-end deficit between the profit that cannot be manipulated and the expected profit target exceeds the amount to allow them for doing accrual manipulation at the end of period.

\subsubsection{Accrual Earnings Management JONES MODEL (1991)}

Jones Model measures non-discretionary accrual including the variable of plant, property, and equipments to control every change of non- discretionary accrual from depreciation and the change in the company's business activities. The accrual discretionary can be obtained by deducting the nondiscretionary accrual from total accruals. By applying regression on the components above, it will be found each regression coefficient that can be used for calculating non-discretionary accrual (NDAC). Consequently, the discretionary accrual, DAC, can be obtained by using this following formula:

DACit $=$ TACit - NDACit

$\mathrm{TA}=\mathrm{Nit}-\mathrm{CFOit}$

Tait/Ait-1 =a1(1/Ait-1 $\Delta)+a 2($ Recit/Ait-1) + a3 (PPEit/Ait1) + it

NDAit $=a 1(1 /$ Ait-1 $)+a 2(\Delta$ Salesit/Ait-1- Recit/ Ait -1) + a3 ( $\triangle$ PPEit/Ait-1)

DAit $=($ TAit/ Ait-1 $)-$ NDAit

Niit $=($ TAit/Ait-1) - NDAit.

If the discreationary accrual value of the company is negative, it means that earnings management done by the company is done by lowering the profit and vice versa.

\subsubsection{Earnings Management through Real Activities Manipulation}

According to Roychowdhury (2006:337), earnings management through real activities manipulation is the management's action that is notwithstanding the company's business practices in normal by achieving the expected profit target as the main purpose. Yet, the profit target that is achieved does not always give a contribution to the firm's value even the target has been achieved. Earnings management through real activities manipulation is performed by the management through company's daily real activities within the current period. Meanwhile, earnings management through accrual manipulation can be done during the current accounting period of the company. According to Roychowdhury (2006: 340), earnings management through real activities manipulation is done through cash flow from operation, production costs, and discretionary expenditures.

\subsubsection{Cash Flow from Operation}

Cash flow from operation is a kind of activity of cash flow report that consists of operating activities in the company. The method used to manipulate the real activities through cash flow from operation is by sales 
manipulation. The sales manipulation is when the manager tries to increase the sales during the accounting period in order to increase the profit in fulfilling the expected profit target. The manager's opportunistic actions through sales manipulation can be done by offering discount on the product price excessively or giving concessional loans. This strategy surely can increase the sales volume and profit. The increased sales volume causes high profit in event year, yet the cash flow is decreased since the low cash inflow as a result of credit sales and discount. Therefore, the activity of sales manipulation causes the decreasing of cash flow from operating activities in current period. Real activities manipulation can be detected through cash flow from operation by using abnormal cash flow from operation (ABN_CFO). Abnormal cash flow from operation is obtained from the difference between actual cash flow from operation (scaled by total assets in previous period before the testing) and cash flow from normal operation activities by using estimated coefficient from the following regression equation.

CFOt /At-1 $=\alpha 0+\alpha 1(1 /$ At- 1$)+\alpha 2($ St $/$ At- 1$)+\alpha 3(\Delta S t$ (At-1) + عt

(Roychowdhury, 2006: 344)

\subsubsection{Discretionary Expenditures}

Discretionary expenditures are the expenses that have no accrual relationship to output. The discretionary expenditures that are used in doing manipulation i.e. advertisement cost, research and Research \& Development (R\&D) cost, sales, general and administration cost. The company can decrease the discretionary expenditures that finally will increase the profit in current period and increase the cash flow in current period if the company, in general, pays the costs using cash. This strategy can increase the profit and cash flow in the next period. Real activities manipulation can be detected through discretionary expenditures by using abnormal discretionary expenditures (ABN_DISEXP). The abnormal discretionary expenditures are obtained from the difference between actual discretionary expenditures (scaled by the total assets in previous period before testing) and normal discretionary expenditures by using estimated coefficient from regression equation model as follows:

DISEXPt/At-1 $=a 0+a 1(1 / A t-1)+\beta(S t / A t-1)+e t$

(Roychowdhury, 2006: 345)

\subsubsection{Production Costs}

Production costs are all expenses or total costs needed to manufacture a product. The method used in doing real manipulation through producing goods is overproduction. The company's management can produce more goods than it should be by assuming that by producing more goods, the fixed cost for per unit of product can be low. This strategy can decrease Cost of Goods Sold (COGS) and increase the operating profit. Real activities manipulation can be detected from the production costs by using abnormal production costs (ABN_PROD). Abnormal production costs can be obtained by seeing the difference between actual production costs (scaled by the total assets in the previous period before testing) and abnormal production costs by using estimated coefficient from the following regression equation model:

PRODt/At-1 $=a 0+a 1(1 /$ At-1) $+\beta 1($ St $/$ At-1 $)+$ $\beta 2(D S t / A t-1)+\beta 3(D S t-1 / A t-1)+e t$

(Roychowdhury, 2006: 345)

Therefore, in this research, abnormal production costs (AbnPROD) would be used. For every firm-year, abnormal production costs is the difference between actual production costs (scaled by total assets in previous period before testing) and normal production costs by using estimated coefficient obtained from the equation model above. As a whole proxy of earnings management through real activities manipulation, the abnormal cash flow from operation (AbnCFO), abnormal discretionary expenditures (AbnDISEXP) and abnormal production costs (AbnPROD) are summed to know the whole effect of earnings management through real activities manipulation. To make the direction equal, the abnormal cash flow cost is multiplied to minus $1(-1)$ and the abnormal discretionary espenditures are multiplied to minus 1 (1) before it is being summed. For the detail, see this following formula:

\section{REAL $=$ AbnCFO * $(-1)+$ AbnDISEXP * $(-1)+$ AbnPROD \\ 2.6. Leverage, Firm Size, and Real Earnings Management}

Many researches analyze about leverage, firm size and earnings management by using various viewpoints and in various environments. These following topics are very interesting and useful for this research: 


\subsubsection{Leverage and Real Earning Management}

The relationship between leverage and earnings management is supported by two hypotheses: debt covenant hypothesis (Watts \& Zimmerman, 1986) and control hypothesis (Jensen, 1986). According to the debt covenant hypothesis, the relationship between leverage and earnings management will be positive since the management can choose the correct accounting method for minimizing the possibility in violating debt covenant. Control hypothesis, in comparison, shows that leverage increases the needs for monitoring and decreasing the available cash for the management to manipulate or to make non-optimal expenditures. Burgstahler and Dichev (1997) and DeGeorge, Patel, and Zechhauser (1999) showed that the investors wanted to monitor the positive results. Therefore, the writers speculated that the company with high leverage ratio had higher incentive for managing their revenues as they had to give good results to their debt holder. Thereby, the debt holder would agree to finance the company again. McConnell e Servaes (1995) and Lang et al. (1996) showed that financial leverage had a negative impact toward the company's investment. It means that the people with higher leverage often have lower investment. Debt covenant hypothesis of positive accounting theory (Watts \& Zimmerman, 1986) reveals that the closer the company is to debt covenant violation, the more the possibility of the company's manager is to choose an accounting procedure which they can change the reported profit from the previous period to the current period. Leverage increases the limitation of the manager's opportunistic behavior because these following reasons: the debt payment needed to decline the available amount of cash for the manager to invest in non-value adding projects. When the company becomes so leveraged, they should face strict supervision from the debt holder and their expenditures are often limited since they are supervised by the debt holder.The previous study was consistent with the prediction of control hypothesis that by increasing the leverage, it can decrease the manager's opportunistic behavior. Ardison et al. (2012) show a finding that there is no relationship between the leverage ratio and earnings management. This finding gives a contribution towards the researcher's literature that analyzes the effect of opportunistic behavior on earnings management and the relationship between leverage and earnings management. This study is a new discovery from the development of our previous research. Previous research was also carried out on mining companies listed on the Indonesian stock exchange in the period 2012 to 2015 . Our previous results showed that leverage did not affect earnings management through discretionary accruals that were calculated by deducting non-discretionary accruals from the total accruals, but earnings management through discretionary accruals, it affects the quality of earnings generated. Where in previous research Earnings management in this study is measured through discreationary accruals which are calculated by disbursing total accruals with non-discreationary accruals by using Total Accrual (TA) classified into Discreationary Accrual (DA) and Non Discreationary Accrual (NDA). In calculating the discreationary accrual, the Modified Jones model is used (Dechow et al., 1995). Previous research can be concluded that the mining company does not take earnings management actions on accrual principles so that it is believed that mining companies apply the principles of accrual method as stipulated in the principles of financial accounting standards in Indonesia (Irene Barus et.al, 2018).

\subsubsection{Firm Size and Real Earning Management}

Naz, Bhatti, Ghafoor, and Khan (2011) investigated the impact of firm size in earnings management and they did not find the statistical significance between the firm size and earnings management in Pakistan. Sun and Rath (2009) analyzed earnings management activities in Australia by analyzing the sample from 4,844 companies within 2000-2006. The finding showed that the small-sized company is more likely to engage in earnings management. The study done by Burgstahler and Dichev (1997) showed that both smallsized and large-sized companies managed the revenue to avoid the decreased or less revenue. Dyreng, Hanlon, and Maydew (2011) found that earnings management in the companies in weak sovereign states was more common than the company that is operated in a location with strong rule of law. They also found some evidences that the profitable company with tax haven manages more revenues that are concentrated in foreign income than other companies did. Most of earnings management happened in domestic income rather than in foreign income. The firm size is various in many ways and it is important to consider how the size affects the information quality that has been reported. This had been argued by Meek et al. (2007) by based on the information asymmetry theory. The large-sized company had fewer information asymmetry since they had strong governance and control so that it directs to the decreasing of earnings management practices. Meanwhile, based on the agency theory, the large-sized company has higher 
agency cost and it means that there are more opportunistic practices happens (Jensen and Meckling 1976). Ahmad et al. (2014) explained that there were some reasons for revealing the negative relationship between the firm size and earnings management. The firm size is a value that can show the scale of the company. Real earnings management is done by the management by showing a good short-term performance of the company. Nevertheless, it potentially decreases the firm's value. It is caused by the management's actions in increasing the current year profit will have a negative impact towards the company performance (profit) in the next period (Roychowdhury 2006). Veronica (2015) found that the firm size had no impact to earnings management. Meanwhile, based on the agency theory, the largesized company has greater agency cost and it indicates that there is more opportunistic practices (Jensen and Meckling, 1976). Nassirzadeh et al. (2012), Kouki et al. (2011), in their research, found that the firm size had a positive impact to earnings management. The management can be motivated to choose the accounting method that can affect the increase of revenue. Myers and Skinner (2000) stated that a largesized company does not expose their actual revenue.

\section{METHODOLOGY/ MATERIALS}

\subsection{Methodology}

This research was a quantitative with an explanatory characteristic that was based on theories. The data used for this research were the secondary data taken from the coal mining companies' financial reports within 2012-2015. The quantitative method attempts to maximize the objectivity, replication, and to generalize the research findings and it is usually more related to a prediction (Harwell, 2011). In this research, it had been done simple linear regression test and multiple regression test both partially and simultaneously to find out the impact between the independent variables toward dependent variables. The population in this research was the whole coal mining companies listed on Indonesia's Stock Exchange from 2012 up to 2015 that were 40 companies in total from the data coal mining companies we get. The sampling in this research used random purposive judgment sampling (Edison, 2018). It means that the companies that are taken as the samples should have these following criteria:

1. The company should be in the list of Indonesia's Stock Exchange consecutively and they should never be out from the list within 2012-2015.
2. The company published the online version of their financial statement within 2012 - 2015.

3. All item accounts existed in the financial statement presented had no value of ' 0 ' within $2012-2015$ consecutively.

4. The parameters for all proxy values needed in these research variables within 2012-2015 should be available.

5. The coal mining companies which become the samples in this research have net worth (total assets) more than a hundred million dollars.

There were 19 coal mining companies which met the five criteria. This research was included as panel data research i.e. data with a characteristic of having large numbers of companies (cross section) and it is analyzed over a period of time (time series). So, based on that thing, the total samples in this research were 19 x $4=76$ observation objects.

\subsection{Materials}

The independent materials of variables in this research were:

a. Leverage as $\mathrm{X} 1$. The variable that was used adopted the formula of total debts/ total assets (Horne and Wachowicz, 2005; Brigham, Eugene and Joel Houston, 2011).

b. Firm Size as X2. The variable that was measured by using natural logarithm from the total assets that was used (Ghazali: 2010, Hasan and Ahmed: 2012).

c. Real Earnings Management as $\mathrm{Y}$. The variable that was used adopted the Real Earnings Management developed by Roychowdhury (Roychowdhury 2006, Cohen et al. 2008; Cohen and Zarowin, 2010) by testing whether the company decreased the discretionary expenditures or did overproduction to influence the revenue. Particularly, they inspected whether the company had low discretionary expenses and high abnormal production costs. Both strategies, overproduction and reducing the discretionary expenditures, would have a positive effect for the revenue. In this point, the previous research had also analyzed if the company were involved in sales manipulation (the increased goods sales manipulation) as the 
strategy of earnings management that could generate abnormal cash flow from operation (CFO) (Roychowdhury: 2006, Cohen et al. 2008, Cohen and Zarowin: 2010). However, overproduction and the increase of artificial sales will have a negative impact to CFO, meanwhile the discretionary expenditures reduction will have a positive impact, and oppose CFO (Roychowdhury 2006). The variable that was used adopted the formula of Real Earnings Management are : abnormal production costs (AbnPROD) would be used. For every firm-year, abnormal production costs is the difference between actual production costs (scaled by total assets in previous period before testing) and normal production costs by using estimated coefficient obtained from the equation model above. As a whole proxy of earnings management through real activities manipulation, the abnormal cash flow from operation (AbnCFO), abnormal discretionary expenditures (AbnDISEXP) and abnormal production costs (AbnPROD) are summed to know the whole effect of earnings management through real activities manipulation. To make the direction equal, the abnormal cash flow cost is multiplied to minus $1(-1)$ and the abnormal discretionary espenditures are multiplied to minus $1(-1)$ before it is being summed. For the detail, see this following formula:

REAL $=$ AbnCFO * $(-1)+$ AbnDISEXP * $(-1)+$ AbnPROD

\section{RESULTS AND FINDINGS}

\subsection{Results}

Besides doing hypothesis testing results in this research, the writer also performed a classical assumption test on multiple regression analysis as follows:

\subsubsection{Normality Test}

The way to know whether the data has been in normal distribution or not is by using the normal distribution figure with the histogram graph which has a curve in bell-shaped (Imam Ghozali, 2011: 164). By seeing the sharpness and the slope of the bell curve at the value between -2.5 and +2.5 , the data had been in normal distribution (Edison Acep, 2018: 204). Based on the figure above, it can be seen that the curve with the bell shaped-histogram graph and the value at the sharpness and the slope of the curve is between -2.5 and +2.5 . Therefore, it can be inferred that based on the curve and the histogram diagram, the regression model fulfills the normality assumption.

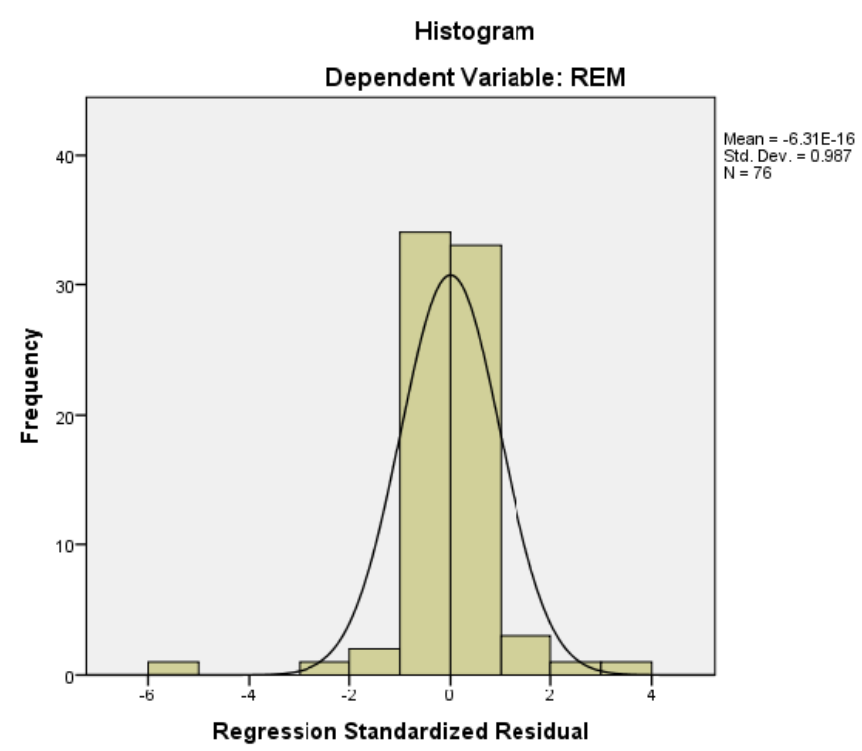

Figure 1: Normality Test.

Source: 24.00 Version SPSS.

\subsubsection{Multicollinearity Test}

Multicollinearity test was a requirement in conducting regression analysis to test whether there was a correlation among the independent variables. Regression analysis should fulfill the requirement that among the independent variable should not have a significant correlation. It means that the values among the independent variables are connected and related to one another. If the values are connected and related, each predictor variable $(X)$ cannot predict the variables that will be predicted independently (Edison 2018: 204). Multicollinearity in regression model can be seen from the value of variance inflation factor (VIF). If the VIF value is greater than 1 (VIF>10), it shows that there is a multicollinearity symptom. Meanwhile, the VIF value that is nearly 1 shows that there is no multicollinearity symptom (Edison 2018: 204; Ghozali, 2011: 108). However, based on Berenson, et al. (2002), VIF value should be less than or equal to 5 .

Based on the table above, it can be seen that all VIF values are below 10 or less than 5 with tolerance value is above 0.10 . Therefore, it could be inferred that there was no multicollinearity symptom among the independent variables.

\subsubsection{Autocorrelation Test}

Autocorrelation test aims to know whether there is correlation among the dependent variables. If there is a 
Table 1: Multicollinearity Test

\begin{tabular}{|c|c|c|c|c|c|c|c|c|}
\hline & \multirow{2}{*}{ Model } & \multicolumn{2}{|c|}{ Unstandardized Coefficients } & \multirow{2}{*}{$\begin{array}{c}\begin{array}{c}\text { Standardized } \\
\text { Coefficients }\end{array} \\
\text { Beta }\end{array}$} & \multirow{2}{*}{$\mathbf{T}$} & \multirow{2}{*}{ Sig. } & \multicolumn{2}{|c|}{ Collinearity Statistics } \\
\hline & & B & Std. Error & & & & Tolerance & VIF \\
\hline \multirow[t]{3}{*}{1} & (Constant) & 227.019 & 58.276 & & 3.896 & $.000^{*}$ & & \\
\hline & LEV & .165 & .078 & .246 & 2.113 & $.038^{*}$ & .844 & 1.185 \\
\hline & FS & -10.609 & 2.830 & -.436 & -3.748 & $.000^{*}$ & .844 & 1.185 \\
\hline
\end{tabular}

${ }^{*} 5 \%$ Significancy Levels, Respectively.

a. Dependent Variable: REM.

Source: 24.00 Version SPSS

correlation, it can be ensured that there is a autocorrelation symptom i.e. the dependent variables in the previous and after the period are being correlated. As consequence of the correlation between the value of dependent variable data between one data to another data, the data can be adjacent or there is an outlier in the data and it causes the certainty level to be distracted and it becomes deviated (Edison 2018: 204). The test that aims to know the autocorrelation could be done by using Durbin-Watson Test. This test results in calculated-DW value $(d)$ and tabulated-DW value $\left(d_{L}\right.$ and $d_{u}$ ). The proportion for decision-making is as follows (Kalayci, 2005). Kalayci stated that to give regression assumption for the research analysis, especially for Durbin-Watson value, it could be done by considering the autocorrelation test became the expected value i.e., around 1.5 and 2.5 (Kalayci, 2005). Meanwhile, according to Edison Acep (2012) and Ghozali Imam (2011), there are some criteria where the data that we had was free from autocorrelation.
1. There is positive autocorrelation if DW value is below $-4(\mathrm{DW}<-4)$

2. There is no autocorrelation if DW value is between -4 and +4 or $-4 \leq \mathrm{DW} \leq+4$.

3. There is negative autocorrelation if DW value is above +4 or $\mathrm{DW}$ value is more than +4 .

Referring to the table above, it shows that the Durbin-Watson value is 1.705 located between -4 and 4 or it can be written as $\mathrm{dL} \leq \mathrm{DW} \leq(4-\mathrm{dU})$. In this research, it was obtained $1.57404 \leq 1.722 \leq$ (4 $1.68185)$, the equation becomes $1.57404 \leq 1.722 \leq$ 2.31815. It could be concluded that there was no autocorrelation in this regression model.

\subsubsection{Heteroscedasticity Test}

This heteroscedasticity test was done to conduct a test toward residual value from a certain data. If the

Table 2: Autocorrelation Test

\begin{tabular}{|c|c|c|c|c|c|c|c|c|c|c|}
\hline \multirow[b]{2}{*}{ Model } & \multirow[b]{2}{*}{$\mathbf{R}$} & \multirow[b]{2}{*}{ R Square } & \multirow{2}{*}{$\begin{array}{l}\text { Adjusted R } \\
\text { Square }\end{array}$} & \multirow{2}{*}{$\begin{array}{l}\text { Std. Error of the } \\
\text { Estimate }\end{array}$} & \multicolumn{5}{|c|}{ Change Statistics } & \multirow{2}{*}{$\begin{array}{l}\text { Durbin- } \\
\text { Watson }\end{array}$} \\
\hline & & & & & R Square Change & F Change & df1 & df2 & $\begin{array}{l}\text { Sig. F } \\
\text { Change }\end{array}$ & \\
\hline 1 & $.407^{\mathrm{a}}$ & .166 & .143 & 77.45709 & .166 & 7.262 & 2 & 73 & $.001^{*}$ & 1.722 \\
\hline
\end{tabular}

${ }^{*} 5 \%$ Significancy Levels, Respectively.

a. Predictors: (Constant), FS, LEV.

b. Dependent Variable: REM.

Source: 24.00 Version SPS.

Table 3: Heteroscedasticity Test

\begin{tabular}{|c|c|c|c|c|c|c|c|c|c|c|c|}
\hline & \multirow{2}{*}{ Model } & \multicolumn{2}{|c|}{$\begin{array}{l}\text { Unstandardized } \\
\text { Coefficients }\end{array}$} & \multirow{2}{*}{\begin{tabular}{|c|}
$\begin{array}{c}\text { Standardized } \\
\text { Coefficients }\end{array}$ \\
Beta \\
\end{tabular}} & \multirow[t]{2}{*}{$\mathbf{T}$} & \multirow{2}{*}{ Sig. } & \multicolumn{3}{|c|}{ Correlations } & \multicolumn{2}{|c|}{ Collinearity Statistics } \\
\hline & & B & Std. Error & & & & Zero-order & Partial & Part & Tolerance & VIF \\
\hline \multirow[t]{3}{*}{1} & (Constant) & $-5.189 E-14$ & 58.276 & & $.000^{*}$ & 1.000 & & & & & \\
\hline & LEV & .000 & .078 & .000 & $.000^{*}$ & 1.000 & .000 & .000 & .000 & .844 & 1.185 \\
\hline & FS & .000 & 2.830 & .000 & $.000^{*}$ & 1.000 & .000 & .000 & .000 & .844 & 1.185 \\
\hline
\end{tabular}

a. ${ }^{*} 5 \%$ Significancy Levels, Respectively.

Dependent Variable: Unstandardized Residual.

Source: 24.00 Version SPSS. 
Table 4: Significance Anova

\begin{tabular}{|c|c|c|c|c|c|c|}
\hline \multicolumn{2}{|c|}{ Model } & Sum of Squares & Df & Mean Square & F & Sig. \\
\hline \hline \multirow{3}{*}{1} & Regression & 87137.532 & 2 & 43568.766 & 7.262 & $.001^{\mathrm{b}}$ \\
\cline { 2 - 7 } & Residual & 437970.873 & 73 & 5999.601 & & \\
\cline { 2 - 7 } & Total & 525108.405 & 75 & & & \\
\hline
\end{tabular}

*5\% Significancy Levels, Respectively.

a. Dependent Variable: REM

b. Predictors: (Constant), FS, LEV.

Source: SPSS Versi 24.00

Table 6: Significance Coefficien

\begin{tabular}{|c|c|c|c|c|c|c|}
\hline & \multirow{2}{*}{ Model } & \multicolumn{2}{|c|}{ Unstandardized Coefficients } & \multirow{2}{*}{$\begin{array}{c}\text { Standardized Coefficients } \\
\text { Beta }\end{array}$} & \multirow{2}{*}{$\mathbf{T}$} & \multirow{2}{*}{ Sig. } \\
\hline & & B & Std. Error & & & \\
\hline \multirow[t]{3}{*}{1} & (Constant) & 227.019 & 58.276 & & 3.896 & $.000^{*}$ \\
\hline & LEV & .165 & .078 & .246 & 2.113 & $.038^{*}$ \\
\hline & FS & -10.609 & 2.830 & -.436 & -3.748 & $.000^{*}$ \\
\hline
\end{tabular}

*5\% Significancy Levels, Respectively.

a. Dependent Variable: REM

Source: SPSS Versi 24.00

residual variance from one observation to another observation is similar, there will be homocedasticity; but, if it happens conversely, there will be heteroscedasticity. Good regression model happens when homocedasticity does not occur. Heteroscedasticity test can be done by using Glejser test, Park test, White test, and Scatterplots test (Edison 2018: 204). In this research, the heteroscedasticity test was done by using Glejser test.

From the figure above, we can see that there is no heteroscedasticity in the variable of leverage and firm size since the significance value $>0.05$. According to the tests that had been done to meet the four requirements in this research, it was found that it fulfilled the criteria. Thereby, the regression equation in this research was qualified for further test i.e. hypothesis testing.

\subsection{Findings}

Besides doing hypothesis testing finding in this research is a significant impact between leverage and real earnings management activities toward firm size in coal mining companies listed on Indonesia's Stock Exchange (BEI) within 2012-2015. The Model Specification: $R E M=\alpha+\beta X 1+\beta X 2+\mu$ (Where: $X 1=$ LEVERAGE, X2 = FIRM_SIZE)

Calculated-F was 7.262 while tabulated- $F$ in this research could be found by calculating as follows: dka $=3-1=2$ and $d k d=76-3=73$. Therefore, tabulated-
$F$ was 3.10. If calculated- $F$ is greater than the tabulated- $F$, it indicates that hypothesis 1 is accepted and vice versa. To know the correlation test of moment product, we can see it from the $\mathrm{R}$ Square. The $\mathrm{R}$ square value was 16.60 percent, indicating that the relationship between the variable of leverage, Firm Size toward REM is very weak. Yet, it could be accepted since the significance value was 0.000 that was below 0.05 and it was below the error. Therefore, the certainty level towards the data could be fulfilled.

From the hypothesis testing, it can be seen that the variable of leverage had positive and significant impact on real earnings management activities while firm size had negative and insignificant impact on real earnings management activities. It can be seen that calculated- $T$ $>$ tabulated-T with the significance level below 0.05 (Sekaran, Uma: 2003). The tabulated-T obtained from this research was 1.9930 with the significance level below 0.05 for the analyzed variables.

\section{CONCLUSION}

The conclusions of this research show that:

1. Calculated- $F$ was 7.262 while tabulated- $F$ in this research could be found by calculating as follows: $\mathrm{dka}=3-1=2$ and $\mathrm{dkd}=76-3=73$. Therefore, tabulated- $F$ was 3.10 . If calculated- $F$ is greater than the tabulated-F, it indicates that hypothesis 1 is accepted and vice versa. To know the correlation test of moment product, we 
can see it from the $\mathrm{R}$ Square. The $\mathrm{R}$ square value was 16.60 percent, indicating that the relationship between the variable of leverage, Firm Size toward REM is very weak. Although the $R$ Square value is quite low, if we associate the currency value into the currency, the value of $16.6 \%$ against the activation manipulation of real management implemented on assets, debt, and profits, shows a considerable number because the company used in this research study is a criterion of large companies. However, it can be accepted since the significance value is 0.000 that is below 0.05 and it is below the error. Therefore, the certainty level towards the data can be fulfilled. The tabulated-T that has been obtained is 1.657, indicating that there is a significant impact since the calculated- $T>$ the tabulated-T at the significance level below 0.05 .It happens because this research only discusses leverage, firm size, and real earnings management activities which frequently occurs as problems in the companies that are analyzed. In addition, it is limited by the amount of company which becomes the object of this research and the period is quite short. Nevertheless, this research is qualified to be tested by using hypothesis testing since it has been fulfilled the criteria of classical assumption test.

2. Among the mining companies that had been analyzed, the variable of leverage and the variable of firm size had significant impact on the variable of real earnings management activities. The variable of leverage gave positive and significant impact on real earnings management activities. It means that if the level of leverage in the company increases by 1 , the variable of real earnings management activities also increases by 0.165 and vice versa. This research finding is contrary to the research done by Ardison et al. (2012). Yet, it is in line with the research findings by Watts \& Zimmerman (1986), Jensen (1986), Burgstahler and Dichev (1997) and DeGeorge, Patel, and Zechhauser (1999). This study is a new discovery from the continuation of our previous research. Previous research was also carried out on mining companies listed on the Indonesian stock exchange in the period 2012 to 2015.This research funding different to the research done by Irene Barus et. al (2018). Our previous results showed that leverage did not affect earnings management through discretionary accruals that were calculated by deducting non-discretionary accruals from the total accruals, but earnings management through discretionary accruals, it affects the quality of earnings generated. Previous research can be concluded that the mining company does not take earnings management actions on accrual principles so that it is believed that mining companies apply the principles of accrual method as stipulated in the principles of financial accounting standards in Indonesia (Irene Barus et.al, 2018). This research is a new work regarding the expansion of previous work.

3. The variable of firm size gave negative and significant impact on real earnings management activities. It means that if firm size decreases by 1 , it will cause the increase in real earnings management activities of 10.609 and vice versa. This research finding opposes the researches done by Jensen and Meckling (1976), Meek et al. (2007), Nassirzadeh et al. (2012), Kouki et al. (2011). In their research findings, it was stated that firm size had positive impact towards earnings management. Nevertheless, it opposes the research findings by Empress (2011) in Veronica (2015), Naz, Bhatti, Ghafoor, and Khan, (2011) stating that firm size (size) has no significant impact towards earnings management. Jensen and Meckling (1976), Nassirzadeh et al. (2012), Kouki et al. (2011), stated in their research findings that firm size has positive impact towards earnings management. Nonetheless, this research is in line with the researches done by Swastika (2013), Tangjitprom (2013), Rezaei and Roshani (2012), and Wuryani (2012). It is found that firm size has negative impact towards earnings management.

4. From the research finding above, it is shown that the variable of leverage and firm size has significant impact on real earnings management activities. This research model that is illustrated in the variables applied in this research can be accepted as the significance level obtained from the independent and dependent variables is below 0.05 .

5. The variable of firm size has a significant negative impact to the real earnings management activities. It indicates that the mining companies including the large-sized 
companies affect the company's management to manage their profit through earnings management practices. It possibly happens because there is less strict supervision from the investor as their audit team in investigating the company's financial report. As a result, the management can perform earnings management practices through daily real activities manipulation. In this research, the mining companies are categorized as the large-sized companies. Even they are considered as the large-sized companies, they do perform earnings management practices. Generally, as the firm size increases, the company does not perform earnings management in the daily real activities. Conversely, if the firm size decreases, the company tends to perform earning The variable of leverage gave positive and significant impact on real earnings management activities. In performing daily activities, the management parties select the accounting method which can reduce the amount of debt as existed in debt covenant to reduce the risk of failure in debt payment. The higher leverage ratio illustrates the management towards the revenue is relatively high. Therefore, the company tends to do earnings management in their daily real operational activities in order that the company is able to pay the company's debt back. The higher level of debt shows that there will be cash inflow in the future. This becomes the company's motivation to do income smoothing. The company's debt levels (leverage) can affect earnings management actions. High leverage occurs because the management manages the company's finance incorrectly or the management applies the incorrect strategy. Due to the less supervision that causes high leverage, the opportunistic actions, such as earnings management, increase to maintain their performances in the shareholders' perceptions and public perception.

6. The variable of firm size gave significant negative impact toward real earnings management activities. It means that the mining companies in this research are included in a type of company that affects the company's management to manage the profit. The negative relationship shows that if the size of large-sized company declines, the manager tends to be aggressive in doing earnings management actions. It usually happens since the decline in sales revenue happens, while the cost rises. As a result, it will lead to the declining profit which also influences the firm size that can be seen from the net worth owned by the company. If the company's profit increases, the company's asset will also increase. It can be seen in form of the expansion or the addition of fixed assets and vice versa. Nevertheless, when the firm size increases, the company tends to not doing earnings management practices since there is strict supervision performed by the investors as their audit team who inspect the company's financial statement. Thereby, the management only can perform earnings management through daily activities. Thus, this research finding shows that the mining companies categorized as the large-sized companies keep on performing earnings management practices in daily activities in order to keep the company's continuity in the future.

\subsection{Recommendation}

The key for achieving the profit target well is a good company performance. If it is from the manipulation they have done and it does not illustrate the real condition of the company, it certainly can decrease the firm size in the future. Based on this research background, this research recommends that:

1. The company should keep monitoring and keep the stability of the total assets value. The company with high total assets value shows that their invested financial capital is high. The ownership of high total assets shows that the company has reached a stage of maturity. At this stage, the ccompany has a positive cash flow and they are considered having good prospects in a relatively long period of time. The company with a high total asset reflects that the company is relatively stable and it is able to generate more profits than the company with fewer total assets has. Besides that the apreiser who plays a role in interpreting the assets owned by the company must have an accurate calculation method in interpreting the fair value of the assets at this time.

2. High strict competition motivates not only the profit obtained but also the raise of the firm's value. It happens since the firm size is not only the reflection of success on the company 
performance but also the illustration of the prospect on the firm's value in the future. The high firm's value is able to attract many investors to the company for investment. The firm size becomes a factor that motivates the company to perform earnings management practices. Therefore, the company should be supervised and should be consistent in selecting the similar accounting method in conducting daily activities based on the General Accepted Accounting Principles (GAAP).

3. Earnings management practices that have been done can cause the management's real activities to be irrelevant to the real condition or it can cause the financial statement to be unqualified and it makes it inappropriate to the ethical principles in business especially the principle of honesty. In this case, the mining companies are expected to apply a stricter supervision in monitoring the control in each transaction through the company's audit team especially for the supervision by the internal control system. The internal control system should be stricter on each activity done by the company in daily, the supervision towards the amount of goods produced, the amount of remaining product in the warehouse, the rising level of debt, the supervision and the impact of the rising assets value owned by the company, the supervision on the cycle of the cash flow, the supervision towards the action in capitalization of interest on debt and the interest for income, the supervision on the use of standard accounting principle that is consistent year by year, the supervision on the revenue obtained from sales, and the operational cost for each transaction in the company. Besides, it is expected that the company's management controls the debt levels owned by the company by doing periodical supervision, applying the correct strategy in managing the debt, cutting ineffective and inefficient expenses, and conducting an upgrading on the product they manufacture so that the sales increases and it results in the rising profit. Thus, it certainly encourages the company's performance to be considered as healthy or good in the shareholders' perceptions and public perception.

4. The government of the Republic of Indonesia should apply a criminal Law and custody for the company that performs manipulation on their financial statement by doing earnings management practices. Earnings management can increase the profit and it can increase the tax for raising the stock price. Yet, earnings management practices can decrease the profit so that the tax can be decreased too and they can avoid high tax payment. Therefore, the real funds that is available from the profit obtained can be used for the importance of the company activities either for financing the operational or for raising the company asset. Each addition on the asset owned by the company indicates an additional revenue that causes the increasing on the profit in the previous years. Meanwhile, according the Law on tax applicable in Indonesia, the company should pay the tax for the increased asset. These earnings management real actions can slow Indonesia's economic growth due to delays in tax payments due to earnings management actions.

5. The current technology development should be able to create an information system software to know whether the company performs earnings management practice in their daily activities or not. Therefore, the company's audit team and the government can detect the company at early time and prevent them to perform earnings management practices.

6. This research discussed leverage, firm size and real earnings management activities only which often become the special concern and frequently become the problems in the companies that are being analyzed. Yet, the amount of the company is limited only for the companies that meet the criteria as the research object and the time is quite short. Therefore, this research can be a reference for the development of scientific knowledge and for further researchers who will conduct a research with a relevant topic. The further researcher could conduct a related research by adding the amount of research variable that is adjusted to the condition of the company that will be an object of the research.

\section{REFERENCES}

Ahmad, M., Anjum, T., Azeem, M. (2014). Investigating the impact of corporate governance on earning management in the presence of firm size: evidence from Pakistan. Vidyabharati International Interdisciplinary Research Journal, 3(2), 84-90.

Anum Mohd Ghazali, N. (2010). Ownership structure, corporate governance and corporate performance in Malaysia. International Journal of Commerce and Management, 20(2), 109-119. https://doi.org/10.1108/10569211011057245 
Alchian, A., \& Demsetz, H. (1972). Production, Information Costs, and Economic Organization. The American Economic Review, 62(5), 777-795. Retrieved from http://www.jstor.org/stable/1815199

Anthony Robert N., Vijay Govindarajan. (2003). Management Control System (1 $11^{\text {th }}$ ed.). New York: McGraw Hill.

Ardison Kym Marcel Martins., Antonio Lopo Martinez., Fernando Caio Galdi. (2012). The effect of leverage on earnings management in brazil. Advances Scientific and Applied Accounting, 5(3), 305-324. https://doi.org/10.14392/ASAA/2012050301

Beatty, A., \& Weber, J. (2003). The Effects of Debt Contracting on Voluntary Accounting Method Changes. The Accounting Review, 78(1), 119-142. https://doi.org/10.2308/accr.2003.78.1.119

Birnberg, JG., Torupolec, L., Young, SM. (1983). The Organizational Context of Accounting. Accounting Organizations and Society, pp. $111-129$. https://doi.org/10.1016/0361-3682(83)90018-1

Brigham Eugene F., Gapenski C Louis. (2007). Financial Management: Theory and Practice $\left(8^{\text {th }}\right.$ ed.). The Dyden Press.

Brigham Eugene F., Houston Joel F. (2011). Fundamentals of Financial Management $\left(7^{\text {th }}\right.$ ed.). Concise Edition. Thomson ONE, Business School Edition.

Burgstahler, D., \& Dichev, I. (1997). Earnings management to avoid earnings decreases and losses. Journal of Accounting and Economics, 24(1), 99-126. https://doi.org/10.1016/S0165-4101(97)00017-7

Clarke, T. (2004). Cycles of Crisis and Regulation: the enduring agency and stewardship problems of corporate governance. Corporate Governance: An International Review, 12(2), 153161. https://doi.org/10.1111/j.1467-8683.2004.00354.x

Cohen, D. A., Dey, A., \& Lys, T. Z. (2008). Real and Accrual-Based Earnings Management in the Pre- and Post-Sarbanes-Oxley Periods. The Accounting Review, 83(3), 757-787. https://doi.org/10.2308/accr.2008.83.3.757

Cohen, D., Zarowin, P. (2010). Accrual-based and real earnings management activities around seasoned equity offerings. Journal of Accounting and Economics, 50(1), pp. 2-19. https://doi.org/10.1016/j.jacceco.2010.01.002

Comer, J. M. (1985). Machiavellianism and Inner vs Outer Directedness: A Study of Sales Managers. Psychological Reports, 56(1), 81-82. https://doi.org/10.2466/pr0.1985.56.1.81

DeFond, M., Jiambalvo, J. (1994). Debt covenant violation and manipulation of accruals. Journal of Accounting and Economics, 17(12), pp. 145-176. https://doi.org/10.1016/0165-4101(94)90008-6

Daily, C. M., Dalton, D. R., \& Cannella, A. A. (2003). Corporate Governance: Decades of Dialogue and Data. The Academy of Management Review, 28(3), 371-382. https://doi.org/10.2307/30040727

Degeorge, F., Patel, J., \& Zeckhauser, R. (1999). Earnings Management to Exceed Thresholds. The Journal of Business, 72(1), 1-33. https://doi.org/10.1086/209601

Dechow, P. (1995). Accounting Earnings and Cash Flows as Measures of Firm Performance: The Role of Accounting Accruals. Joumal of Accounting and Economics, 18, pp. 3-42. https://doi.org/10.1016/0165-4101(94)90016-7

Dechow, P. M., Sloan, R. G., \& Sweeney, A. P. (1995). Detecting Earnings Management. The Accounting Review, 70(2), 193225. Retrieved from http://www.jstor.org/stable/248303

Dechow, P. M., Kothari, S. P., \& Watts, R. (1998). The relation between earnings and cash flows. Journal of Accounting and Economics, 25(2), 133-168. https://doi.org/10.1016/S0165-4101(98)00020-2
Dechow, P. M., \& Skinner, D. J. (2000). Earnings Management: Reconciling the Views of Accounting Academics, Practitioners, and Regulators. Accounting Horizons, 14(2), 235-250.

https://doi.org/10.2308/acch.2000.14.2.235

Dyreng, S. D., Hanlon, M., \& Maydew, E. L. (2010). The Effects of Executives on Corporate Tax Avoidance. The Accounting Review, 85(4), 1163-1189. https://doi.org/10.2308/accr.2010.85.4.1163

Edison Acep. (2018). Metode Penelitian Bisnis ( $1^{\text {th }}$ ed.). Bandung : CENDRA.

Gable, M., \& Dangello, F. (1994). Locus of Control, Machiavellianism, and Managerial Job Performance. The Journal of Psychology, 128(5), 599-608. https://doi.org/10.1080/00223980.1994.9914917

Gombolaa, Michael J., Amy Yueh-Fang Ho., Chin-Chuan Huang. (2016). The effect of leverage and liquidity on earnings and capital management: Evidence from U.S.commercial banks. International Review of Economics and Finance, 43(1), 3558.

https://doi.org/10.1016/j.iref.2015.10.030

Hansen, Don R., Maryanne M, Mowen. (2005). Management Accounting. Jakarta : Erlangga.

Harwell, M. R. (2011). Research design: Qualitative, quantitative, and mixed methods: Pursuing ideas as the keystone of exemplary inquir. In C. Conrad, \& R. C. Serlin (Eds.), The Sage handbook for research in education: Pursuing ideas as the keystone of exemplary inquir (Second Edition ed.). Thousand Oaks, CA: Sage.

Hassan Shehu Usman., Abubakar Ahmed. (2012). Corporate governance, earnings management and financial performance: A case of Nigerian manufacturing firms. American international journal of contemporary research, 2(7), 214-226. Retrieved from https://pdfs.semanticscholar. org/96b8/0f4a69e9986cc236250ce69cf5cab2b987a3.pdf

Hoang, Q. X., Biger, N., \& Nguyen, N. V. Chapter 15 The determinants of capital structure: Evidence from Vietnam Asia-Pacific Financial Markets: Integration, Innovation and Challenges (pp. 307-326).

Horne Van, Wachowicz. (2005). Fundamentals of Financial Management $\left(12^{\text {th }}\right.$ ed.). Pearson Education Limited.

Imam Ghozali. (2011). Aplikasi Analisis Multivariate dengan Program IBM SPSS 19. Semarang : Badan Penerbit Universitas Diponegoro.

Indonesia Stock Exchange. Financial Statement 2012 until 2015. Jakarta : www.idx.co.id

Irene Sukma Lestari Barus, Tetty Lasniroha Sarumpaet, Renny Maisyarah, Edrida Pulungan. (2018). Apakah Manajemen Laba merupakan Variabel Intervening (Unti Analisis Perusahaan Pertambangan BEI Periode 2012-2015). Jurnal Akuntansi, Keuangan \& Perpajakkan Indonesia (JAKPI), $6(1)$, 39-53. Retrieved from https://jurnal.unimed.ac.id/ 2012/index.php/eua/issue/view/1430

Jaggi, Bikki \& Lee, Picheng. (2002). Earnings Management Response to Debt Covenant Violations and Debt Restructuring. Journal of Accounting, Auditing \& Finance. 17. https://doi.org/10.1177/0148558X0201700402

Jaworski, B. J., \& Young, S. M. (1992). Dysfunctional behavior and management control: An empirical study of marketing managers. Accounting, Organizations and Society, 17(1), 1735 https://doi.org/10.1016/0361-3682(92)90034-P

Jensen M C., Meckling W H. (1976). Theory of the firm: Managerial behavior, agency costs and ownership structure. Journal of financial economics, 3(4), 305-360. https://doi.org/10.1016/0304-405X(76)90026-X

Jensen, M. C. (1986). Agency Costs of Free Cash Flow, Corporate Finance, and Takeovers. The American Economic Review, 
76(2), 323-329. Retrieved from http://www.jstor.org/stable/ 1818789

Jha, A. (2013). Earnings Management Around Debt-Covenant Violations - An Empirical Investigation Using a Large Sample of Quarterly Data. Journal of Accounting, Auditing \& Finance, 28(4), 369-396. https://doi.org/10.1177/0148558X13505597

Kalayci Seref. (2005). SPSS Applications, Multi-variables Statistics Techniques $\left(1^{\text {th }}\right.$ ed.). Ankara Turkey : Asil Publish.

Kerr, S., Schriesheim, C., Murphy, C. J., \& Stogdill, R. M. (1974). Toward a contingency theory of leadership based upon the consideration and initiating structure literature. Organizational Behavior and Human Performance, 12(1), 6282. https://doi.org/10.1016/0030-5073(74)90037-3

Kouki, M., Elkhaldi, A., Atri, H., \& Souid, S. (2011). Does corporate governance constrain earnings management? Evidence from U.S. firms.

Lang, L., Ofek, E., \& Stulz, R. (1996). Leverage, investment, and firm growth. Journal of Financial Economics, 40(1), 3-29. https://doi.org/10.1016/0304-405X(95)00842-3

McConnell, J. J., \& Servaes, H. (1995). Equity ownership and the two faces of debt. Journal of Financial Economics, 39(1), 131157. https://doi.org/10.1016/0304-405X(95)00824-X

Meek, G. K., Rao, R. P., \& Skousen, C. J. (2007). Evidence on factors affecting the relationship between CEO stock option compensation and earnings management. Review of Accounting and Finance, 6(3), 304-323. https://doi.org/10.1108/14757700710778036

Naz, I., Bhatti, K., Ghafoor, A., \& Khan, H. (2011). Impact of firm size and capital structure on earnings management: Evidence from Pakistan (Vol. 2)

Nassirzadeh, Farzaneh, Mahdi Salehi, Sayed Mohammad Alei. (2012). A Study of The Factor Affecting Earnings Management: Iranian Overview. Science Series Data Report, 4(2), 22-27. Retrieved from https://profdoc.um.ac.ir/articles/a/ 1027081.pdf.

Pamela Peterson, Fabozzi Frank J. (2003). Financial Management \& Analysis $\left(2^{\text {th }}\right.$ ed.). New Jersey : John Wiley \& Sons, Inc.

Rezaei Farzin, Maryam Roshani. (2012). Efficient or Opportunistic Earnings Management with Regards to The Role of Firm Size and Corporate Governance Practices. Interdisciplinary Journal of Contemporary Research in Business, 3(9), 13121322. Retrieved from https://journal-archieves14.webs.com/ 1312-1322.pdf

Ridgway, V. F. (1956). Dysfunctional Consequences of Performance Measurements. Administrative Science Quarterly, 1. https://doi.org/10.2307/2390989

Roychowdhury, S. (2006). Earnings management through real activities manipulation. Journal of Accounting and Economics, 42(3), 335-370.

https://doi.org/10.1016/j.jacceco.2006.01.002
Sekaran, Uma. (2003). Research Methods for Business: A Skill Building Approach $\left(4^{\text {th }}\right.$ ed.). John Wiley \& Sons Inc.

Sekaran, Uma, Roger Bougie. (2011). Research Methods for Business a Skill Building Approach ( $5^{\text {th }}$ ed.). UK : John Wiley \& Sons Ltd.

Scott, William R. (2003). Financial Accounting Theory $\left(3^{\text {th }}\right.$ ed.). Canada : Prentice-Hall.

Seitz, Neil. (1984). Financial Analysis: A Programmed Approach $\left(3^{\text {th }}\right.$ ed.). Englewood Cliffs. New Jersey : A Reston Book Prentice-Hall, Inc.

Solar, D., \& Bruehl, D. (1971). Machiavellianism and Locus of Control: Two Conceptions of Interpersonal Power. Psychological Reports, 29(3 suppl), 1079-1082. https://doi.org/10.2466/pro.1971.29.3f.1079

Stice, James D., Stice EarlK., Fred Skousen K. (2007). Intermediate Accounting $\left(16^{\text {th }}\right.$ ed.). Thomson South-Western.

Sun, L. and Rath, S. 2009. An empirical analysis of earnings management in Australia. International Journal of Business, Economics, Finance and Management Sciences, 1(2), 150166. Retrieved from https://pdfs.semanticscholar.org/c660/ 597038436299ad2b1497c91a09fe9b561187.pdf

Swastika, Dwi Lusi Tyasiang. (2013). Corporate Governance, Firm Size, and Earnings Management: Evidence in Indonesia Stock Exchange. IOSR Journal of Economics and Finance (IOSR-JEF), 10(4), 77-82. https://doi.org/10.9790/487X-1047782

Sweeney, A. P. (1994). Debt-covenant violations and managers' accounting responses. Journal of Accounting and Economics, 17(3), 281-308. https://doi.org/10.1016/0165-4101(94)90030-2

Tangjitprom, Nopphon, 2013, 'The Role of Corporate Governance in Reducing the Negative Effect of Earnings Management', International Journal of Economics and Finance, 5(3), 213220. https://doi.org/10.5539/ijef.v5n3p213

Van Horne, James C, John M. (2008). Fundamentals of Financial Management $\left(13^{\text {th }}\right.$ ed.). Pearson Education Limited. Prentice Hall.

Veronica, Aries. (2015). The Influence of Leverage and Its Size on the Earnings Management. Research Journal of Finance and Accounting, 6(8), 159 - 167. Retrieved from https://iiste.org/Journals/index.php/RJFA/article/view/21985

Watts, R, J. Zimmerman. (1986). Positive Accounting Theory. Prentice-Hall, Englewood Cliffs, NJ.

Wuryani, Eni. (2012). Company Size in Response To Earnings Management And Company Performance. Journal of Economics, Business, and Accountancy Ventura, 15(3), pp. 491- 506.

https://doi.org/10.14414/jebav.v15i3.117

Zang, A. Y. (2012). Evidence on the Trade-Off between Real Activities Manipulation and Accrual-Based Earnings Management. The Accounting Review, 87(2), 675-703. https://doi.org/10.2308/accr-10196

\section{DOI: https://doi.org/10.6000/1929-7092.2019.08.58}

(C) 2019 Barus et al.; Licensee Lifescience Global.

This is an open access article licensed under the terms of the Creative Commons Attribution Non-Commercial License (http://creativecommons.org/licenses/by-nc/3.0/) which permits unrestricted, non-commercial use, distribution and reproduction in any medium, provided the work is properly cited. 